\title{
Superior divisional oculomotor paresis due to intracavernous internal carotid artery aneurysm
}

Figure Nine gaze photographs and cerebral angiography
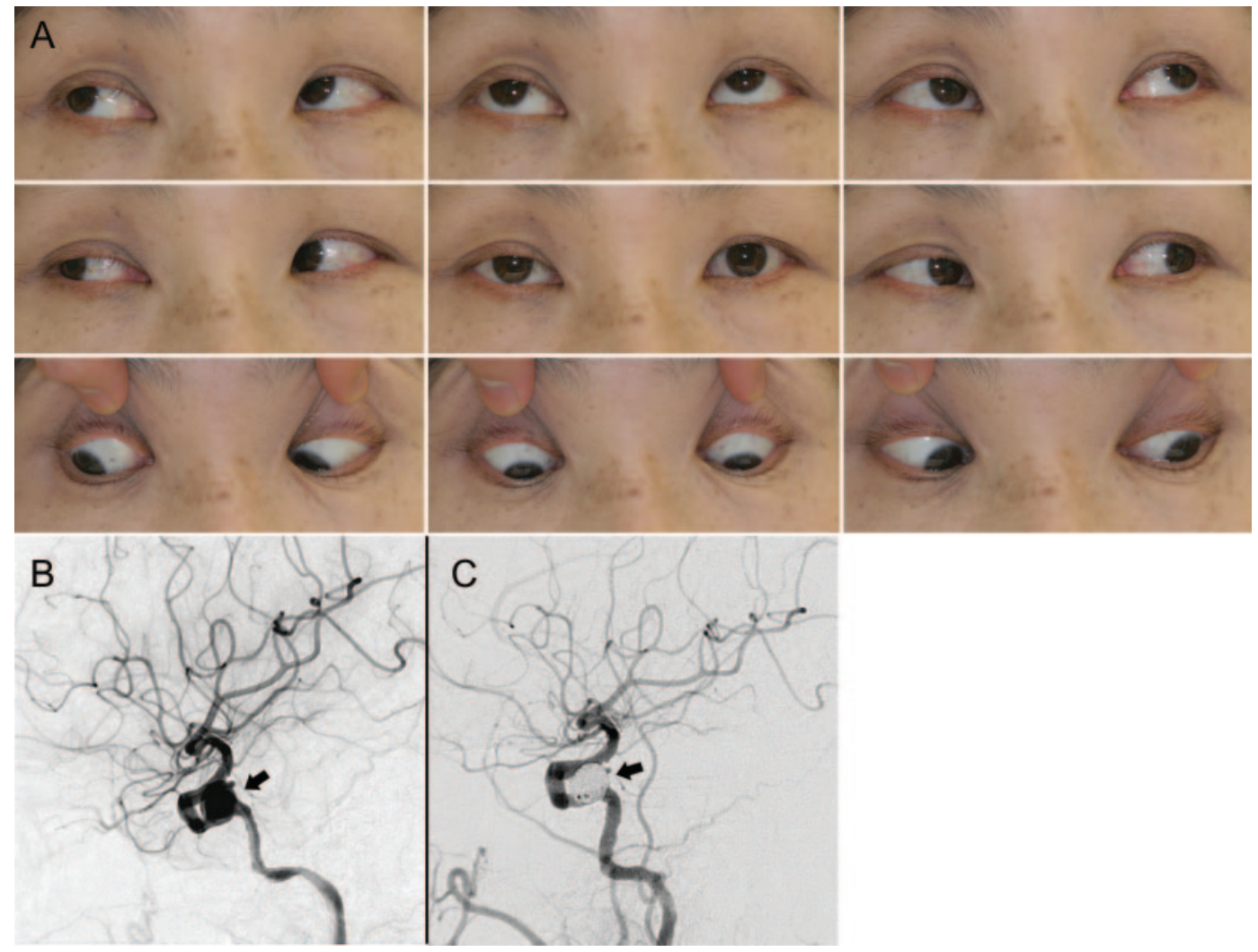

Nine gaze photographs show mild ptosis and limitation of elevation in the right eye (A). Cerebral angiography discloses a saccular aneurysm in the cavernous portion of the right internal carotid artery (B) which was treated with coil embolization (C).

A 49-year-old woman presented with vertical diplopia, drooping of the right eyelid, and right-sided retroorbital pain for 10 days. Examination revealed ptosis, hypotropia, and elevation paresis in the right eye (figure, A). Other findings were normal, including the pupils. MRI and cerebral angiography disclosed a right-sided intracavernous carotid aneurysm (figure, B) that was treated with coil embolization (figure, C).

Superior divisional oculomotor paresis is characterized by ptosis and superior rectus palsy. ${ }^{1,2}$ Divisional oculomotor palsy usually indicates a lesion in the anterior cavernous sinus or superior orbital fissure since the oculomotor nerve branches into superior and interior divisions in those areas. ${ }^{1}$

Joo Young Kwon, MD, Hyun Seok Song, MD, Ji Soo Kim, MD, Seoul, Korea

Supported by a grant from the Korea Health 21 R\&D Project, Ministry of Health \& Welfare, Republic of Korea (A080750).

Disclosure: The authors report no disclosures.

Address correspondence and reprint requests to Dr. Ji Soo Kim, Department of Neurology, Seoul National University College of Medicine, Seoul National University Bundang Hospital, 300 Gumi-dong, Bundang-gu, Seongnam-si, Gyeonggi-do, 463-707, Korea; jisookim@snu.ac.kr

1. Burde RM, Savino PJ, Trobe JD, eds. Clinical Decisions in Neuro-ophthalmology, 3rd ed. St. Louis: Mosby; 2002.

2. Trobe JD, Glaser JS, Post JD. Meningiomas and aneurysms of the cavernous sinus: neuro-ophthalmologic features. Arch Ophthalmol 1978;96:457-467. 


\section{Neurology}

\section{Superior divisional oculomotor paresis due to intracavernous internal carotid artery aneurysm}

Joo Young Kwon, Hyun Seok Song and Ji Soo Kim

Neurology 2009;72;1875

DOI 10.1212/WNL.0b013e3181a7124f

This information is current as of May 26, 2009

Updated Information \& Services

References

Subspecialty Collections

Permissions \& Licensing

Reprints including high resolution figures, can be found at: http://n.neurology.org/content/72/21/1875.full

This article cites 1 articles, 0 of which you can access for free at: http://n.neurology.org/content/72/21/1875.full\#ref-list-1

This article, along with others on similar topics, appears in the following collection(s):

Diplopia (double vision)

http://n.neurology.org/cgi/collection/diplopia_double_vision Eyelids

http://n.neurology.org/cgi/collection/eyelids

Ocular motility

http://n.neurology.org/cgi/collection/ocular_motility

Other cerebrovascular disease/ Stroke

http://n.neurology.org/cgi/collection/other_cerebrovascular_disease_st roke

Information about reproducing this article in parts (figures,tables) or in its entirety can be found online at:

http://www.neurology.org/about/about_the_journal\#permissions

Information about ordering reprints can be found online:

http://n.neurology.org/subscribers/advertise

Neurology ${ }^{\circledR}$ is the official journal of the American Academy of Neurology. Published continuously since 1951, it is now a weekly with 48 issues per year. Copyright . All rights reserved. Print ISSN: 0028-3878. Online ISSN: 1526-632X.

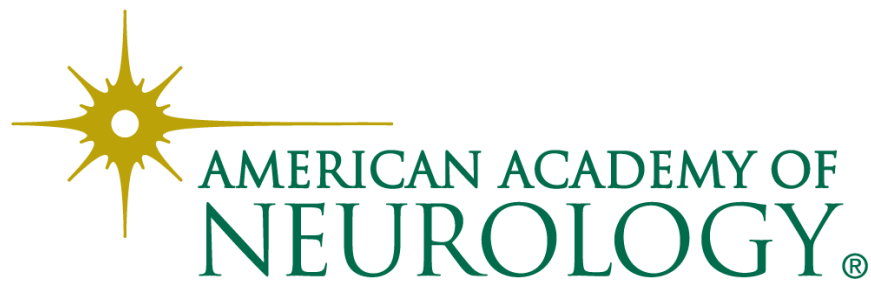

